INTERNATIONAL JOURNAL OF

MANAGEMENT STUDIES

http://e-journal.uum.edu.my/index.php/ijms

How to cite this article:

Hussain, M., \& Mubarik, S. (2021). Measuring human resource attitude using organisational theory of relationship: The way forward. International Journal of Management Studies, 28(1), 57-88. https://doi.org/10.32890/ijms.28.1.2021.9409

\title{
MEASURING HUMAN RESOURCE ATTITUDE USING ORGANISATIONAL THEORY OF RELATIONSHIP: THE WAY FORWARD
}

\author{
${ }^{1}$ Munir Hussain \& ${ }^{2}$ Shujaat Mubarik \\ ${ }^{1}$ Faculty of Management Sciences \\ Barrett Hodgson University, Pakistan \\ ${ }^{2}$ College of Business Management \\ Institute of Business Management, Pakistan
}

${ }^{1}$ Corresponding author: munir.hussain@bhu.edu.pk

Received: 3/4/2020 Revised: 7/10/2020 Accepted: 13/10/2020 Published: 27/1/2021

\begin{abstract}
This paper argues that classical socialisation theories generally discuss the organisational structures rather than the newcomer's psychology of relationships in any organisation and contributes to the socialisation stage model. In doing so, this research proposes an Organisational Theory of Relationship (OTR) for understanding the relationships of human resources in any organisation in four stages, namely fascination, contention, adaptation and adoration. The four stages have been examined in an empirical setting based on the data collected from 270 participants. Using the structural equation modelling, the measurement model validity was ascertained and several hypotheses were tested. The findings reveal that all employees in any organisation, intentionally or unintentionally, undergo some or
\end{abstract}


all of the four stages. This model can provide a better insight into the organisational socialisation and individualism of its human resource. It also recommends the organisations to adopt the best possible strategies for uplifting employees' psychological engagement to utilise their full potentials. The findings of the study can help to understand socialisation in relation to interpersonal relationships and provide a foundation for making socialisation in the organisation better.

Keywords: Organisational theory of relationship, organisational socialisation, attitudes, stage model, human resource.

\section{INTRODUCTION}

Attitudes and behaviours play pivotal roles in establishing organisational culture as shed by the available literature. The literature can be divided into two groups, namely social psychologists (Kinder \& Sear, 1985; Krosnick \& Alwin, 1989) and developmental psychologists (Sigelman \& Shaffer, 1991). The authors particularly discuss the measures of attitude development, but many other researchers examine them explicitly in the framework of organisational behaviour or organisational socialisation (Arnold et al., 1992). This paper aims to establish a theory of relationship to socialise human resources in organisations.

Boudreau and Ramstad (2003) argue that intellectual capital has become a sustainable competitive advantage for an organisation. According to Steel (2002), Lee and Mitchell (1994), Othman and Shkuri (2015), and Parsons (2018), the employee's turnover process was and the temporal interaction between work attitudes and an organisation was not fully captured. Meanwhile, Steel (2002) worked on the theory of attitude with relation to employee turnover. Such awareness can provide a better interplay between the employee retention and organisational settings. Employees' retention mostly relies on organisational socialisation (OS) theories. Organisational socialisation (OS) is defined as a process of learning the ropes (Schein, 1968, p.2), which enables the employees to acquire competence and knowledge necessary to improve their profession or organisation. This process is acquired through vicarious observations and active participation of new entrants in an organisation for becoming the 
active members (Parsons, 2018). Furthermore, OS is a pivotal process of communicating the organisational culture and acquisition (Harrison \& Caroll, 1991; Schein, 1990). In addition, the OS is also recognised as an essential organisational function (Fogarthy \& Dirsmith, 2001) that refers to the involvement in the organisational culture (Inzerille \& Rosen, 1983; Meek,1988). OS is a way to produce full-fledged and productive human resources (Louis, 1980; Van Maanen \& Schein, 1979). Furthermore, OS can increase the organiszational proficiency of employees towards understanding of the organisational culture, norms, roles, roles, expectations and responsibilities (Ashforth et al. 2007). Khalil et al. (2021) connect the relationship of age with socialisation, whereas Cai et al. (2020) investigate the impact of social media on the newcomers' socialisation. The authors approve that socialisation has a significant impact on adjusting new employees to the job, group and organisation (Bauer et al., 1998; Fisher, 1986; Moreland \& Levine, 2001; Saks \& Ashforth, 1997).

\section{LITERATURE REVIEW}

\section{Stages of Socialisation}

Many authors have developed the processes or stages of socialisation. This can be traced back to Feldman (1976), who first explained the three stages of socialisation, including anticipatory socialisation, accommodation, and role-management. The first stage, as per Feldman (1976), refers to the anticipation of a newcomer in which realistic expectations are required for getting in new talent into the organisation. The second stage suits a newcomer with the organisational work setting to set in. This stage even applies to organisational conflict resolution. This model explicitly outlines the processes of socialising a newcomer, but the discussion of counterparts' relationships in this model is scarce.

Similarly, Buchanan (1974) depicts a three-stage early career model for training of employees from first to the fifth year of employment, but its emphasis is on training and development rather than relationship management as a tool of socialisation. Another remarkable theory was the three-stage entry model by Porter et al. (1975) in which they categorise the stages of socialising an employee into the pre- 
arrival, encounte, and change/acquisition stages. First, the prearrival stage encompasses the basic idea of socialisation that starts before the arrival of a newcomer in an organisation. The encounter stage starts from the first working day of an employee. This stage clarifies the difference between expectations and realities within the organisation. Dean et al. (1985) proclaim this stage as reality shock in which a newcomer's expectations come into conflict. Even the duration of this stage is not empirically defined, but Louis (1980) roughly estimates it as occurring from the first six to nine months. The last stage depicts mutual acceptance (Schein, 1978) or settling in (Feldman, 1976) while an employee gets the mastery of work and fulfils the demands of a job. Schein (1978) articulates another psychological three-stage model in which the stage entry refers to the arrival of a newcomer. At this stage, the newcomer's information is not based on personally observable facts. Therefore, a newcomer tries to get accurate information. After getting appropriate information, the newcomer moves up to the second stage of socialisation in which he/ she accepts the organisational reality, adjusts with personal conflicts and resistance to change. After successful completion of this stage, a newcomer moves to the third stage of mutual acceptance that leads to full organisation-employee acceptance for each other.

Another notable socialisation theory is Wanous' (1980) integrative model of socialisation. It elaborates that a newcomer experiences four stages while becoming an active member of any organisation. The first stage, as shared by Wanous, is called confronting which is similar to the stage of encounter (Porter et al., 1975) and entry (Schein, 1978). At this stage, the new entrant confronts the organisational reality and confirms or disconfirms its own expectations with the organisational reality. At this first stage, unlike Porter et al's (1975) and Schein's (1978), conflict arises while the newcomer compares the personal and organisational values and climates. At the same place, the new employee discovers the rewards or punishment behaviours. The second stage in this model is achieving the role clarity in which a newcomer copes with resistance to change, defines the interpersonal relations and copes with organisational structure and ambiguities. A third stage twitches a newcomer to locate himself in the organisational context by learning the behaviours of others according to organisational expectations. At this stage, conflicts are normally resolved, work problems lead to organisational commitments and 
newcomers establish interpersonal relationships by embracing new organisational beliefs. Effective socialisation is the last stage in which organisational trustworthiness and commitment are improved, high organisational satisfaction is attained, and intrinsic motivation are enhanced (Wanous, 1980).

Ashforth et al. (2007) rightly mention that even socialisation stage models have remarkable importance but have not received much attention and there is a need for valuable research on the stage modelling. Early research supports the stage models of socialisation, but there is a gap in developing a universal stage model. Fisher (1986) notifies explicitly the need for a comprehensive universal stage model that can be equally applicable for all organisations, jobs and employees irrespective of diverse organisational cultures. Furthermore, Bauer et al. (1998) notify that stage models are mainly focused on the characterising of each stage instead of discussing how the learning and adjustment changes occur.

Moreover, we find that most of the stage models of socialisation mainly discuss the processes instead of discussing the level of relationship. We found a U-curve theory of adjustment by Lysgaard (1955) that was developed for an entirely different purpose of crosscultural adaptation of expatriates or sojourners. Even this model was designed specifically for the sojourners, but it provides an insight into the social relationship. Lysgaard's theory explains that an individual comes to an entirely new host culture, and this first stage is called the honeymoon stage, while the individual gets fascinated by a new culture, environment, and relations. After a while, the individual comes to a stage of cultural shock in which new entrant's internal frustration occurs. The third stage was named as an adjustment stage in which a person starts adopting a new culture and transforms the behaviour based on the requirements of the host country. The fourth and last stage is called the mastery stage in which a person increases the ability to function more effectively in a host country. The U-Curve theory and Cultural Shock theory by Oberg (1960) were developed in intercultural environments of expatriates and sojourners working abroad, but Coffman and Harris (1984) and Pedersen (1995) generalsze the adjustment stages to other social roles of cultural exchange including divorce, office jobs, retirement, nursing, bereavement, economic change, college life, office jobs, medical 
school, paraplegia, psychiatric residency, careers and haemodialysis. Black and Mendenhall (1991) relate this adjustment theory with the relation of marriage. This argument leads to the socialisation of newcomers in organisations in relation to U-curve theory focusing on the cross-national environment.

Afterward, Lesser and Peter (1957) propose another three-stage model for adjustment, including stages of spectator, involvement, and coming-to-term stage. Even these models are for sojourners who work in a new country or region, but these adjustment theories provide a good insight on relationship development in entirely a different environment. In addition to the stage models, Rojas (2017) explicitly mentions that there are few socialisation-based functions and mechanisms involved in link between organisation and newcomer's socialisation. In his empirical experiments he supports the socialisation functions and mechanism over strict stages or states of socialisation.

Bullis (1993) mentions that to date, most research on organisational socialisation is focused on either socialisation or individualiaation. She predicts that future studies should concentrate on the interplay of socialisation stages because it will enable researchers with a variety of integrated analyses and results.

This paper is an attempt to focus on an interplay between socialisation and individualiaation of organisational newcomers in which each stage had been investigated tusing thestatistical method. This scarcity leads us to develop a new organisational theory of relationship (OTR) that can fill the gap of a new stage model as mentioned by previous authors, in particular, Fisher (1986). This model explicitly discusses the levels of relationships, not only the structures. Based on this model, the organisations may set strategies and tactics for each level of OTR.

In 2020, the pandemic COVID-19 situation has changed the way we live, interact with others and specifically, has affected the organisational socialisation. Chadha (2020) is right to depict that organisations have to rapidly adjust their ways of working during the COVID-19 pandemic. Furthermore, during this pandemic the organisational cultures are under much strain due to the change of social relations and shift of work from workplace to home and vice versa. Authors are also 
finding tips and solutions to deal with the post-COVID-19 situation in relation to work from home. McDonough et al. (2020) mention three tips for keeping employees out of working burnouts including setting physical and social boundaries, maintaining temporal boundaries and focus on the most important work. This emphasis shows that modern authors are looking forward to the new ways for maintaining good organisational culture and socialisation. However, new studies show that honeymoon period of work from home is declining in postCOVID situations and employees are realising the uncertainty of this method (English, 2020; Boddy, 2020). In this context (both in pre and post COVID-19), the proposed model of OTR will be a good remedy for organisational socialisation.

\section{Organisational Theory of Relationship (OTR)}

The organisational theory of relationship (OTR) shows the better interplay between the organisational socialisation and individualism of its human resource. Furthermore, it will help to understand the organisational socialisation in relation to interpersonal relationship. It will also provide a foundation for making a better socialisation structure in an organisation.

\section{Fascination Stage}

This is the first stage of socialisation when an employee enters the organisation. Wanous (1980) calls this stage as confronting, Porter et al. (1975) refers to it as encounter, Schein (1978) labels it as entry and Lysgaard (1955), and Oberg (1960) address it from a cross-cultural perspective, that is, the honeymoon stage.

Boswell et al. (2005) specifically propose that there is a honeymoon phase when a newcomer enters an organisation. They claim this a honeymoon effect while the early experiences of an employee in an organisation are mainly positive. At this stage, new employee experiences a new culture, system, structure, norms, people, hierarchy of command and environment. Van Maanen and Schien (1979) notifies that usually, organisations show their most favourable side to the candidates during the recruitment process.

At first instance, newcomers have the motivation to get information and knowledge of organisation for reducing their uncertainties about 
the job and professional accommodation (Bauer et al., 2007; Kim et al., 2005). For making their place in the organisation, newcomers have a high level of interest to contribute using their professional expertise (Kristof-Brown et al., 2005). Walker et al. (2013) argue that newcomers use the tactic of social interaction that enables an employee to get the trustworthiness of the employer and it leads to influence the work attitudes. From the perspective of cultural-shock theorists, at this stage, everything is new, exciting and fascinating (Irwin, 2007). At first glance of the organisation, the newcomers get fantasised. They have a feeling of surprise and wishful thinking of the work setting and job. New entrants believe that the job and organisation meet their values and expect positive experiences from the other side (Louis, 1980). This surprise could be positive or negative. Just like a newly married couple, a newcomer has a glamour to see a new culture, work settings, norms, people, chain of relations and command and symbols whereas the 'natives' or previous employees are courteous, polite and welcoming. Frese (1982) mentions that the newcomers get fantasised about the new job, want to get more information about the job and organisation and adjust themselves with this new environment and culture. This is also a stage of enthusiasm and fascination (Ward et al., 1998, p.278), where newcomers are ambitious to prove that their selection is right. This stage can also be described as the tourist's experience. In a cross-cultural environment, the tourists mostly fall in this stage where they get fascinated, excited and enthusiastic, and this stage ends when they complete their short stay, but the longerstay people may move to other states. In organisational perspectives, the employees who move to other organisations in a short period for training or visit purpose may face the same fascination.

Few other authors describe the fascinating stage as the stage of having new exciting sights and sounds with excitement (Black \& Mendenhall 1991, p. 226), a high level of satisfaction and trust (Klineberg \& Hull, 1979), euphoric stage (Oxenfeldt \& Kelly, 1968). Levinthal and Fichman (1988) relate this stage of fascination or honeymoon with the commitment and belief that this excitement leads to employee commitment. Harris (2017) claims that the newly hired employees fall in a honeymoon phase where they have limitless possibilities, receive tons of attention and learn a lot from their new organisation and co-workers. 
Boswell et al. (2005) mention that the level of honeymoon effect may be lower if an employee moves to a more mediocre organisation or there is a lower poorer-fit with the new job or organisation. Moreover, people who have plentiful job opportunities in the industry might exhibit a stronger honeymoon effect. Their initial euphoria increases by the perception that their new job achieved an excellent alternative from others. They also mention that the timing of a job change may also impact on increase or decrease of honeymoon effect. Furthermore, they studied the honeymoon effect during a job switching in the same organisation with relation to internal transfers or promotions. This stage may be affected by some job or organisation-specific factors, including the change of position, job or place. The findings of Bowell et al. (2005) were explicitly for high-level-managers, but there is a need to investigate it among other levels of employees.

Kaplan (1995) discusses the fascination explicitly as stimuli that attract ones' interest. He argues that fascination forces involuntary attention (James, 1892) and there is no need for directed attention if the fascination process is appropriate and adequate. James (1892) argues that involuntary attention (Kaplan claims it as fascination) is the best attention because it is effortless, otherwise directed attention. As Berto et al. (2010) mention, it creates attentional fatigue. Therefore, fascination inherently grips the attention and people effortlessly adopt it. Kaplan (1995) further divides fascination into two parts; soft and hard fascination. Soft fascination characterises with the natural settings such as clouds, sunsets, snow, leaves in the breeze and ocean waves (Kaplan \& Kaplan, 1989) On the other hand, hard fascination mainly entails loud noises, fast motion and/or another strong stimulus those attract the attention (Kaplan \& Berman, 2010).

Fascination should have significant relationship with socialisation as indicated in the above literature. Hartig et al. (1996) and Laumann et al. (2001) developed instruments for measuring fascination but those are mainly related to general socialisation. Hence, we developed hypothesis to test the relationship between fascination and socialisation.

Hypothesis 1: There is a positive relationship between fascination and socialisation. 


\section{Contention Stage}

Authors claim that entering a new organisation and adjusting with a new culture is a stressing exercise (Nelson, 1987). Stressors may be positive, including potential rewards, challenges and opportunities or harmful, including tension-producing transition, feeling of loneliness and social isolation (Nelson, 1987; Katz, 1978, Van Maanen \& Schein, 1979). Schein (1971) claims such stressor as a performance anxiety whilst Allen et al. (1999) and Kammeyer-Mueller et al. (2012) viewed it as burnout and ambiguity respectively that affects the task-mastery of newcomers. Organisational stress emerges due to organisational demands and coping techniques mismanagement (Bhagat \& Beehr, 1984; Quick \& Quick, 1984). Jackson et al. (1987) investigate that there is uncertainty involved with new tasks, job, roles and organisational relationship that produces stress in newcomers. Similarly, Saks et al. (2007) and Bauer et al. (1998) relate the organisational stress of a newcomer to the roles of conflict and role ambiguity.

Conflict theories also support this stage. Rahim (1977) categorises conflict into two parts; intrapersonal and interpersonal conflicts. Intrapersonal conflict is within a person, whereas interpersonal conflict is further divided into intragroup, intergroup and inter-organisational conflicts. Rahim (1977) also mentions that when a newcomer joins a group, the group stability may be disrupted that can cause a conflict and the newcomer may be significantly affected.

Nifadkar and Bauer (2016) confirm that there was limited literature available on examining the effect of relationship conflict on a newcomer. They contribute to specifically discussing the adjustment model for handling relationship conflict in context to newcomer's adjustment.

After the encounter with an organisation, the newly appointed employees become involved with acquiring new information that can clarify their roles and adjusting behaviours with the expectations of organisation. During this involvement, the newcomers interact with the organisational members and work settings (Yang, 2008). Furthermore, they may act proactively and this behaviour may change the status quo (Crant, 2000) that may surprise others and increase the possibilities or occurrence of a conflict. 
Louis (1980) explicitly illustrates this stage by discussing the psychological context of surprise. This surprise is associated with a conflict between the employees' expectations and organisational realities. Pondy (1969) believes that even the conflict among relations is unpleasant, but it is inevitable in organisational relations. Even Pondy accepts the dysfunctional conflict as a reality and this should be accepted as a necessary condition.

Furthermore, Pondy (1992) mentions that conflict provides a higher quality of decision making with diverse opinions. This argument defines that naturally, there is a chance of conflict in all relations; therefore, it should be taken as a natural phenomenon. These conflicts arise due to asymmetric interdependence of the groups (Kumar et al. 1995), personal incompatibility (Peterson \& Behfar, 2003) stress and threats (Thomas, 1992), disputant behaviours with relation to jealousy, hatred, anger and frustration (Ross \& Ross, 1989).

The stage of fascination no longer exists when newcomers face new types of relations, the hierarchy of command, work settings and culture. Similarly, they move to a condition of unrest, unpleasant feelings, stress, or conflict while the glamour of job and organisation moves towards the realities. In the stage of fascination, all mountains look green and the newcomer has a feeling of honeymoon-hangover effect (Boswell et al., 2005). Nevertheless, these feelings last temporarily and newcomer's idealistic attitudes bump with the realities. The example can be illustrated by referring tom a newly married couple with each person has romantic and glamourised feelings for each other and fantasizes love and affection.

After a while, however, there are few differences are found in the new couple such as society, fashion, lifestyle, and these differences directly impact the idealistic feelings of each other. Similarly, there are differences between the idealism of the newcomer and the realities of an organisation. Some newcomers leave the job and organisations due to these differences (Griffeth et al., 2000; March \& Simon, 1958; Steers \& Mowday, 1981), some spend a long time enduring such experiences and feelings even for the whole organisational tenure, with these conflicting feelings and some move to the next stage of adaptation. 
In light of the above literature review, it is expected that contention is correlated with socialisation. This hypothesis was motivated to develop mainly by several studies (Berry et al., 1992; Dean et al., 1985; Hill \& Grüner, 1973; Lysgaard, 1955; Modlin \& Faris, 1956; Oberg, 1960; Tuckman 1965; Wanous, 1980).

Hypothesis 2: There is a positive relationship between contention and socialisation.

\section{Adaptation Stage}

In the discussion of adjustment of sojourners, Oberg (1955) describes that after the honeymoon period, a person moves to the stage of adjustment in which newcomer removes the anxiety, although there are moments of strain. This strain removes after a complete grasp on social intercourse. At this stage, a person not only accepts the new culture with food, habits and customs but starts to enjoy them. In an organisational context, the adjustment is typically a process of individual acquiring knowledge about the job and organisation and to adjust the work settings (Fisher, 1986; Van Maanen \& Schein, 1979). The previous studies show that during this stage of adaptation, newcomers' behaviours of resistance are controlled by others, specifically the administrators of new organisations (Callister \& Wall, 2001; Ferlie et al., 2005; Zabusky \& Barley, 1997).

Many authors believe that this stage is an adjustment, adaptation, or rehabilitation of previous contention or conflict stage, in which newcomers give full professional expertise. Furthermore, these authors emphasise the organisations to adopt the best possible options for making this process smooth to enable socialisation objectives to be accomplished (Katz, 1978; Nelson, 1987; Oberg, 1960; Schein, 1971; Van Maanen \& Schein, 1979).

Nevertheless, there are few strains (Oberg, 1960) and one strain is the fear of rejection by the organisation, thus the employees in such conditions keep silent on conflicting matters (Deutsch \& Gerard, 1955). This stage can be better understood with the example of a newly-wed couple who crossed the honeymoon period from the stage of fascination, resolved the conflicts and differences at the stage of contention and now adjusting with each other. There are differences between them, but they have ways to avoid conflicting matters, 
understand the limitations, and compromise whether anyone finds any weakness in another party.

Job adaptive theories, more specifically, explain this stage. Adaptive behaviour or performance characterises as a person's ability to adapt the dynamic workplace situations. (Hesketh \& Neal, 1999). This behaviour requires employees to adjust to work settings (Pulakos et al., 2000). Therefore, the authors highlight the importance of adaptive behaviour in different ways (Allworth \& Hesketh, 1996; CharbonnierVoirin \& Roussel, 2012; Hollenbeck et al., 1996; London \& Mone, 1999). Pulakos et al. (2000) revolutionise the adaptive behavioural theories with a new scientific model of eight dimensions of adaptive performance, including learning new tasks, handling work stress, demonstrating interpersonal adaptability, technologie, and procedures, cultural and physically oriented adaptability. Different authors later developed many scales of measuring employees' adaptation.

Nevertheless, there was a need to understand the other side of adaptive theories. Hulin (1991) argues that job adaptive behaviour emerges in response to the unpleasant and non-satisfactory working conditions. Moreover, Boswell et al. (2014) believe that there is a correlation between adaptive work behaviour and job insecurity. They also argue that the adaptive behaviours, for the employee and organisation, may have negative consequences and an individual's responses may lead to defensive behaviour. The literature leads us to focus on the psychological adjustment process of newcomers in organisations. It was hypothesised that there is a correlation between the stage of adaptation and socialisation.

Hypothesis 3: There is a positive relationship between adaptation and socialisation.

\section{Adoration Stage}

Rattner and Danzer (2006) argue that adoration, admiration, or reverence are essential tools for the growth and development of a human personality. Many authors use the admiration and adoration as mixtures of more essential elements of emotion. Father of Evolution theory, Darwin (1890/2007) connects admiration with astonishment and claims that this feeling of astonishment is associated with 
the feeling of pleasure and a sense of acceptance. The authors claim adoration as the elevation of morale (Algoe \& Haidt, 2009; Haidt, 2003), a form of respect (Li \& Fischer, 2007), a feeling of someone superior and exemplary (Solomon, 1976/1993), a stage of being inspired by (Thrash \& Elliot, 2004), intense and passionate attachment, strongly associated with romantic love (Schindler et al., 2013), emotional relation and happiness (Mees, 1985), predominantly outer focus (Smith, 2000), transcendent emotions (Peterson \& Seligman, 2004) and a stage of actualisation (Ortony et al., 1988). Few authors connect the relation of admiration with physiological changes (Immordino-Yan et al., 2009; Immordino-Yang \& Sylvan, 2010). There is scarce literature available on discussing adoration and admiration in organisational context. Only very few studies are available on leadership commitment (Burns, 1978; Carlton-Ford, 1992; Conger et al., 2000).

Love theories also support the stage of adoration and authors cover the association between organisational love and employee engagement. Aron and Aron (1996) relate the adoration and admiration with love. Baer (2007) describes love as care for others and commitment to their welfare and claims it as real love. Koestenbaum (2002) claims the surrender of one's freedom for the other party as love. Tasselli (2018) defines explicitly that love can shape the behaviour of employees ontologically that directly impacts on their organisational roles. He further emphasises that employees change their behaviours after understanding the organisation whilst love can provide them a continuous and authentic realisation of themselves and their association with others and the organisation. Similarly, the researchers mentioned that adjustment and socialisation are correlated. We developed a construct of adaptation including all aspects of adjustment and adaptive behaviour for hypothesising the correlation for testing this model.

Hypothesis 4: There is a positive relationship between adoration and socialisation.

The socialisation authors believe that there is a correlation between adoration and socialisation and we hypothesised to find the relation in organisational framework specifically on the newcomers. (Bauer et al., 1998; Ashforth et al. 2007; Fisher, 1986). Figure 1 represents the conceptual framework of the study. 


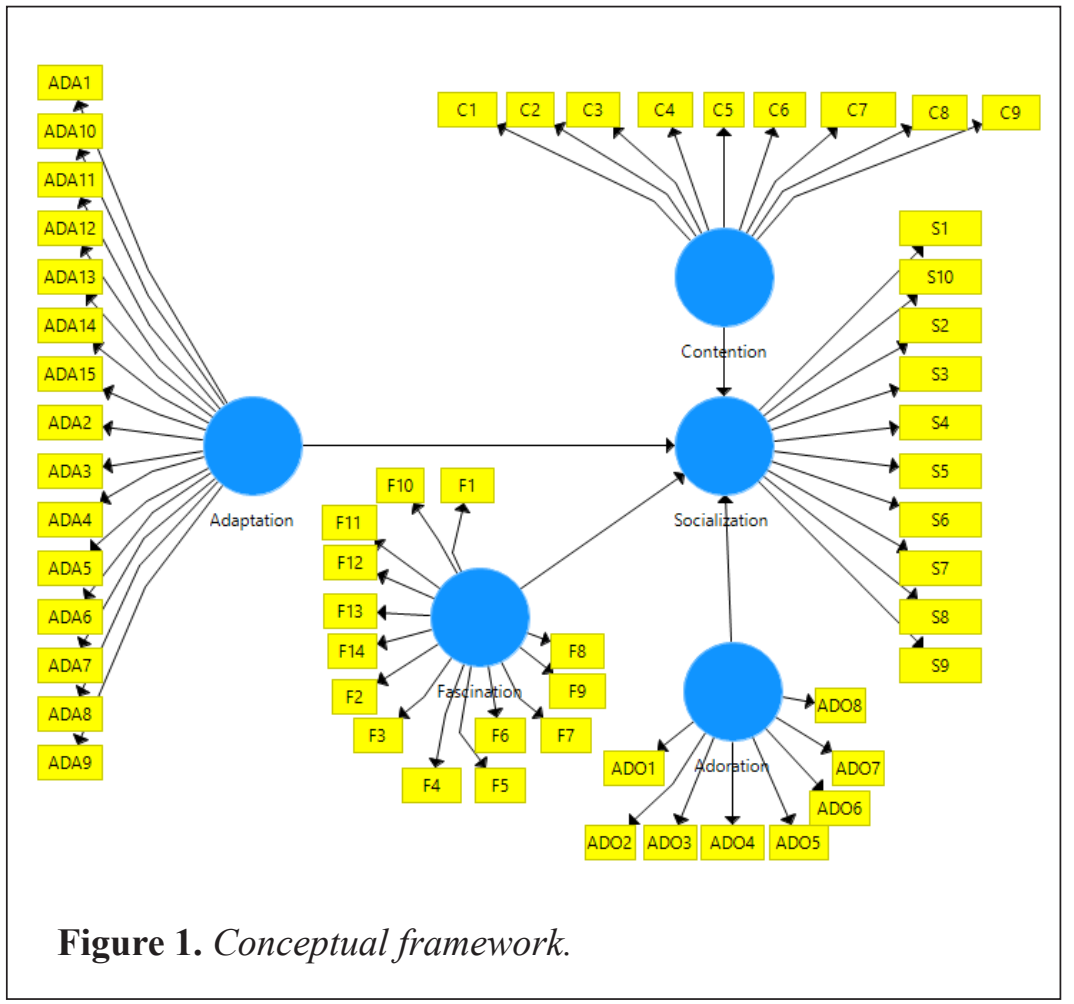

\section{METHODOLOGY}

\section{Population and Sampling}

This research was conducted on the employees working in Pakistani organisations from different sectors. For the sampling population, we chose the students of executive MBA from four higher education institutions (three universities and one institute). These students were selected as convenience samples who study during the evenings or weekends and work in the different sectors of industry for the purpose of examining stages of employees. They were able to provide the best possible concerns of their population. Using the Google form as research instrument, the survey was distributed through Facebook, LinkedIn and Twitter accounts (mainly the on-job students). This survey was conducted during the spring and fall semesters of 2019. 
Among 300 completed questionnaires, thirty (30) were omitted due to several reasons; because they were only students (not working anywhere), entrepreneurs, unemployed, they submitted incomplete responses or the persons had a job during less than two years (rejection ratio was 10\%). For our research, the respondents had few years experience and faced many stages of socialisation within the organisations. In responding to the statements of the independent variable called Fascination, they conveyed that they should keep their first six to nine months in mind since Louise (1980) implies that this period lasts for six to nine months. Hence, the rejection ratio of invalid responses was 5.5 percent.

\section{Measures and Measurements}

The measures of the construct for socialisation were adapted by Haueter et al. 2003. The construct contains ten items as S1, S2, S3, S4, S5, S6, S7, S9 and S10. The measures for fascination were derived from Hartig et al. (1996) and Laumann et al. (2001). Hartig et al. (1996) developed a perceived restoration scale (PRS) that provides a comprehensive set of descriptive measures for the construct of fascination. Among all sixteen items of Hartig et al. (1996), we adapted nine descriptive items for our questionnaire. Secondly, we found another set of measures by Laumann et al. (2001).

Among all twenty-two descriptive, we found five items most suitable for our questionnaire. The measures of both authors were essentially designed to general sociology and we needed to focus on the organisational framework, therefore, we only selected those which were most suited to the organisational environment. The construct had a total of fourteen items, all measured on the Likert scale of 1 to 5. A set of statements was compiled for measuring the attitudes of employees within their first six months (as suggested by Louise, the period of honeymoon lasts for six months).

Hence, the construct for the stage of contention, was adapted from Nifadkar and Bauer (2016), while sixteen items were adapted from Charbonnier-Voirina and Roussel (2012) for the construct of Adaptation and eight items were adapted from Schindler et al. (2013) for the construct of adoration. We employed PLS-Structural equation 
modelling (PLS-SEM) to analyse the hypothesised relationships. This method is suitable for the theory confirmation; however, it requires normality of the variables at the individual and group level (Hair et al., 2016).

\section{RESULTS}

The reliability and validity of measurement models were determined through Confirmatory Factor Analysis (CFA). Hair et al. (2016) mention that the factor loading, average variance extracted and composite reliability are essential tests for evaluating the convergent validity and internal reliability of a measurement model. Hence, the threshold values for factor loading, AVE and CR were 0.70, 0.50 and 0.70 respectively. Nevertheless, factor loading value can be relaxed up to 0.50 , keeping in view the AVE (Hair et al., 2016). Furthermore, Fornell-Larcker (FL) criteria by Fornell and Larcker (1981) were employed for examining the discriminant validity of the construct.

The criteria compare the AVE's square-rooted values with the interconstruct correlation. The value of square rooted AVE should be higher than the inter-construct correlation to obtain the discriminant validity. Our results for convergent validity and internal reliability, showed that all construct had the values of greater than the abovementioned threshold values and showed the convergent validity. Likewise, Fornell-Larcker (FL) criteria showed that all constructs had discriminant validity. For ascertaining the overall model fitness, we used the techniques of SRMR and CFI. The value of SRMR was 0.061 (par $<0.08$ ) and CFI was 0.912 (par $>0.90$ ) that showed a strong model fitness. Whereas, the R-value of this model was 0.63 that showed the strong goodness-fit of the model. (See Table 1, Table 2, and Table 3).

The $p$-values of all coefficients Fascination, Contention, Adaptation and Adoration depicted a significant positive impact of these four dimensions on socialisation. By comparing the results, we found that adaptation $(\beta=0.28, p<0.000)$ had a highest impact on socialisation followed by adoration $(\beta=0.22, p<0.000)$, contention $(\beta=0.18$, $p<0.05)$ and fascination $(\beta=0.12, \mathrm{p}<0.05)$. In the proceeding section, we discussed in detail as to why these relationships were significant and what can be concluded from the policy implication. 
Table 1

Measurement Model

\begin{tabular}{|c|c|c|c|c|c|}
\hline Construct & Item & Loadings & AVE & $\mathrm{CR}$ & $\begin{array}{c}\text { CB } \\
\text { Alpha }\end{array}$ \\
\hline \multirow[t]{13}{*}{ Adaptation } & ADA3 & 0.67 & 0.59 & 0.89 & 0.87 \\
\hline & ADA4 & 0.76 & & & \\
\hline & ADA5 & 0.77 & & & \\
\hline & ADA6 & 0.83 & & & \\
\hline & ADA7 & 0.94 & & & \\
\hline & ADA8 & 0.75 & & & \\
\hline & ADA9 & 0.77 & & & \\
\hline & ADA10 & 0.86 & & & \\
\hline & ADA11 & 0.77 & & & \\
\hline & ADA12 & 0.69 & & & \\
\hline & ADA13 & 0.71 & & & \\
\hline & ADA14 & 0.74 & & & \\
\hline & ADA15 & 0.81 & & & \\
\hline \multirow[t]{12}{*}{ Fascination } & F3 & 0.73 & 0.56 & 0.85 & 0.92 \\
\hline & F5 & 0.74 & & & \\
\hline & F6 & 0.79 & & & \\
\hline & F7 & 0.68 & & & \\
\hline & F8 & 0.69 & & & \\
\hline & F9 & 0.86 & & & \\
\hline & F10 & 0.81 & & & \\
\hline & F11 & 0.71 & & & \\
\hline & F12 & 0.76 & & & \\
\hline & F13 & 0.74 & & & \\
\hline & F14 & 0.75 & & & \\
\hline & F15 & 0.74 & & & \\
\hline \multirow[t]{8}{*}{ Adoration } & ADO1 & 0.71 & 0.58 & 0.91 & 0.93 \\
\hline & $\mathrm{ADO} 2$ & 0.73 & & & \\
\hline & $\mathrm{ADO} 3$ & 0.78 & & & \\
\hline & ADO4 & 0.84 & & & \\
\hline & ADO5 & 0.81 & & & \\
\hline & ADO6 & 0.71 & & & \\
\hline & $\mathrm{ADO} 7$ & 0.74 & & & \\
\hline & $\mathrm{ADO} 8$ & 0.73 & & & \\
\hline
\end{tabular}

(continued) 


\begin{tabular}{llcccc}
\hline Construct & Item & Loadings & AVE & CR & $\begin{array}{c}\text { CB } \\
\text { Alpha }\end{array}$ \\
\hline Socialisation & S3 & 0.76 & 0.63 & 0.93 & 94 \\
& S4 & 0.74 & & & \\
& S5 & 0.87 & & & \\
& S6 & 0.81 & & & \\
& S7 & 0.91 & & & \\
& S8 & 0.74 & & & \\
& S9 & 0.69 & & & \\
& S10 & 0.81 & & & \\
& C1 & 0.74 & 0.59 & 0.89 & 0.85 \\
& C3 & 0.71 & & & \\
& C4 & 0.69 & & & \\
& C6 & 0.86 & & & \\
& C7 & 0.79 & & & \\
& C8 & 0.81 & & & \\
\hline
\end{tabular}

Note.

a. Item loadings $\geq 0.7$ indicate indicator reliability (Chin, 1998b; Götz et al., 2010; Hair et al., 2011; Hulland, 1999; Latan \& Ghozali, 2012a).

b. Average Variance Extracted (AVE) $>0.5$ indicates Convergent Validity (Bagozzi \& Yi, 1988; Fornell \& Larcker, 1981).

c. Composite Reliability $(\mathrm{CR})>0.7$ indicates Internal Consistency (Gefen et al., 2000).

d. $\quad$ B alpha $>0.7$ indicates indicator reliability (Dijkstra \& Henseler, 2015).

\section{Table 2}

Fornel-Larcker Criteria

\begin{tabular}{lcccc}
\hline & Adaptation & Adoration & Contention & Fascination \\
\hline Adaptation & $\mathbf{0 . 7 7}$ & & & \\
Adoration & 0.24 & $\mathbf{0 . 7 5}$ & & \\
Contention & 0.35 & 0.41 & $\mathbf{0 . 7 6}$ & \\
Fascination & 0.29 & 0.45 & 0.72 & $\mathbf{0 . 7 7}$ \\
\hline
\end{tabular}

Note. Diagonal values are the square root of AVE. 


\section{Table 3}

Hypothesis Testing's

\begin{tabular}{lccc}
\hline Path & Beta & $p$-value & Decision \\
\hline Adaptation $\longrightarrow$ Socialisation & 0.28 & 0.000 & Supported \\
Adoration $\longrightarrow$ Socialisation & 0.22 & 0.000 & Supported \\
Contention $\longrightarrow$ Socialisation & 0.18 & 0.001 & Supported \\
Fascination $\longrightarrow$ Socialisation & 0.12 & 0.012 & Supported \\
R-Square & 0.63 & & \\
f-Square & 0.39 & & \\
Q Square & 0.29 & & \\
SRMR & 0.061 & & \\
GFI & 0.901 & & \\
CFI & 0.912 & & \\
RMSEA & 0.068 & & \\
\hline
\end{tabular}

Note. R-square values of $0.75,0.50$, and 0.25 represent substantial, moderate and weak model respectively. f- square, effect size is according to Cohen (1988), f 2 values 0.35 (large), 0.15 (medium), and 0.02 (small). q-square, predictive relevance of predictor exogenous variables as according to Henseler et al. (2009), q2 values 0.35 (large), 0.15 (medium), and 0.02 (small). SRMR and CFI are the values used to ascertain the overall model fitness. For model fitness SRMR $<.08, \mathrm{CFI}>0.90$.

\section{DISCUSSION AND IMPLICATION}

The objective of the study was to test the applicability of a fourstage model in the context of Pakistan. For doing so, we employed the structural equation modelling on the data collected from the 270 samples from service and manufacturing sector. The results confirm the arguments of Boswell et al. (2005), Van Maanen \& Schein, 1979) and Kaplan (1995) that the newcomers in the organisation, encounter the stage of fascination that is also known as the honeymoon period. They get fascinated to be a part of an organisation that they envisaged for. New culture, welcoming managers and co-workers, set of relations, work settings etc. initially everything inspires and fascinates them. The stage of fascination can be increased if a person's dissatisfaction with the previous organisation was high, if faced a longer period of unemployment or if he or she dreamed about being 
a part of new organisation. This stage can be unrealistic or euphoric. Human resource departments use the induction, orientation and introductory programmes for providing realistic knowledge to enable them to exchange their unrealistic approach to something realistic. At this stage, organisational knowledge, co-worker's cooperation, clear organisational culture can be useful remedies for adjusting a newcomer.

The period of fascination ends soon while the difference of newcomer's expectations and organisation occurs. Our results affirm Lahana et al.'s (2019), Gross and Guerrero's (2000), Bauer et al.'s (1998) and Van Maanen and Schein's (1979) 's claims on the stage of contention. At this time, a newcomer starts to disagree or mentally opposes the differences. Thus the stage of mind changes to an internal conflict or crisis. Simultaneously, a newcomer has two choices; leaving the organisation or start arguing on the differences. We observe that many people in organisations may struck in the stage of conflict that is because of opposition, critics, blaming or whistle-blowing attitude. Most of the time these people do not leave the organisation due to unavailability of new opportunities and keep working with the stress and conflicting relations.

Furthermore, this research validates the claim of He et al.'s (2019), Grant-Vallone and Ensher's (2001), and Charbonnier-Voirina and Roussel(2012) that the stage of conflict or contention leads to the stage of adaptation in which a person gets few give-ways for dealing with conflict-related matters. At this stage, newcomers get successful in removing the anxiety, stress, conflict, unrest and adjust with new conditions along with some personal grievances. On the other hand, some of them start thinking differently. At this point, they start extracting positives from negatives and move to the stage of adoration. This is stage of absolute love where a person is psychologically attached and ready to work in out-of-box situations.

Finally, this research also confirms the impact of adoration and admiration on the socialisation of newcomers as mentioned by Schindler et al. (2013) and Rattner and Danzer (2006). The results reveal that all the four stages Fascination, Contention, Adaptation, Adoration exert the significant positive impact on socialisation. The employees entering in an organisation get adjusted in any of these four stages and spend the majority of their organisational life in the particular stage(s). The results show the importance of recognising the socialisation stage of newcomers, their expectations for others and 
their psychological bonding with the organisational culture. Thus, a practical implication of this model is that the organisations should focus on the social components in dealing with the newcomers. The organisation and newcomer may benefit if such interactions transpire among employees. In addition, socialisation tactics can work better if documented well and mechanism are adequately defined. This study sheds light on the relationship between psychological contracts of employees and socialisation tactics and recommends future research for further examination of such concern.

\section{CONCLUSION}

This paper investigate whether four(4) stages of fascination, contention, adaptation and adoration play any role in developing and maintaining employees' organisation socialisation. Even the role of theses stages, particularly for shaping behaviours of individual employees, has often been neglected in favour of more cognitive explanations. The literature review of this paper also explored a theoretical gap that addressed in this research. This research revealed that the four stages shared earlier play important roles in socialising newcomers to accept new experiences and meanings which either reinforce or change their values, goals and identities. In sum, the organisations and their departments of human resources are working hard to hire and maintain best talents. The model putforth in this paper can help classify the employees into four stages and set their organisational strategies to make them more productive. The model reflects the psychology of newcomers as it_demonstrates the significance of understanding the newcomers' psychological stages of socialisation, their aspirations towards others and their relations with the organisation.

\section{ACKNOWLEDGEMENT}

The authors would like to extend their gratitude to the anonymous referees for their comments and the Editor(s) for their kind consideration. Further, the authors received no financial support for the research, authorship and/or publication of this article.

\section{REFERENCES}

Algoe, S. B., \& Haidt, J. (2009). Witnessing excellence in action: The other-praising emotions of elevation, gratitude, and admiration. The Journal of Positive Psychology, 4, 105-127. 
Allen, T. D., McManus, S. E., \& Russell, J. E. A. (1999). Newcomer socialisation and stress: Formal peer relationships as a source of support. Journal of Vocational Behaviour, 54, 453-470.

Allworth, E. A., \& Hesketh, B. (1996). Construct-based biodata and the prediction of adaptive performance. 12th Annual Conference of the Society for Industrial and Organisational Psychology. St. Louis, MO.

Arnold, H. J., Feldman, D. C., \& Hunt, G. (1992). Organisational behaviour: A Canadian perspective. Toronto: McGraw-Hill.

Aron, E. N., \& Aron, A. (1996). Love and expansion of the self: The state of the model. Personal Relationships, 3, 45-58. https:// doi.org/10.1111/j.1475-6811.1996.tb00103.x

Ashforth, B., Sluss, D. M., \& Harrison, S. H. (2007). Socialisation in organisational contexts. International Review of Industrial and Organisational Psychology. 22, 1-70. https://doi.org/ 10.1002/9780470753378.ch1

Baer, G. (2007). Real love in the workplace: Eight principles for consistently effective leadership in business. Rome: Blueridge Press.

Bagozzi, R., \& Yi, Y. (1988). On the evaluation of structural equation models. Journal of the Academy of Marketing Sciences, 16, 74 -94. http://dx.doi.org/10.1007/BF02723327

Bauer, T. N., Morrison, E. W., \& Callister, R. R. (1998). Organisational socialisation: A review and directions for future research. Research in Personnel and Human Resources Management, 16, 149-214.

Bauer, T. N., Bodner, T., Erdogan, B., Truxillo, D. M., \& Tucker, J. S. (2007). Newcomer adjustment during organisational socialisation: A meta-analytic review of antecedents, outcomes, and methods. Journal of Applied Psychology, 92(3), 707-721.

Berry, J. W., Poortinga, Y. H., Segall, M. H., \& Dasen, P. J. (1992). Cross-cultural sychology: Research and applications. Cambridge: Cambridge University Press.

Berto, R., Baroni, M. R., Zainaghi,A., \& Bettella, S. (2010). An exploratory study of the effect of high and low fascination environments on attentional fatigue. Journal of Environmental Psychology, 30(4), 494-500. https://doi.org/10.1016/j.jenvp.2009.12.002

Bhagat, R. S., \& Beehr, T. A. (1984). An evaluative summary and recommendations for future research. In T. A. Beehr, \& R. S. Bhagat, (Eds.), Human stress and cognition in organisations: An integrated perspective (pp. 417-431). New York: John Wiley.

Black, S. J., \& Mark, M. (1991). The U-curve adjustment hypothesis revisited: A review and theoretical framework. Journal of International Business Studies, 22(2), 225-247. 
Boddy, N. (2020). Is the work from home honeymoon is over? Financial Review. https://www.afr.com/work-and-careers/careers/is-thework-from-home-honeymoon-over-20200501-p54ozx

Boswell, W. R., Olson-Buchanan, J. B., \& Harris, T. (2014). I cannot afford to have a life: Employee adaptation to feelings of job insecurity. Personnel Psychology, 67(4), 887-915. https://doi. org /10.1111/peps.12061

Boswell, W. R., John W. B., \& Tichy, J. (2005). The relationship between job change and job satisfaction: The honeymoonhangover-effect. Journal of Applied Psychology, 90, 882-892.

Boudreau, J. W., \& Ramstad, P. M. (2003). Strategic HRM measurement in the 21st century: From justifying HR to strategic talent leadership. In M. Goldsmith., R. P. Gandossy, \& M. S. Efron (Eds.), HRM in the 21st century (pp 79-90). New York: John Wiley.

Buchanan, B. (1974). Building organisational commitment: The socialisation of managers in work organisations. Administrative Science Quarterly, 19, 533-546.

Bullis, C. (1993). Organisational socialisation research: Enabling, constraining, and shifting perspectives. Communication Monographs, 60(1), 10-17. doi: https://doi. org/10.1080/03637759309376289

Burns, J. M. (1978). Leadership. New York, NY: Harper \& Row.

Cai, D., Liu, J., Zhao, H., \& Li, M. (2020). Could social media help in newcomers' socialisation? The moderating effect of newcomers' utilitarian motivation. Computers in Human Behaviour, 106273. https://doi.org/10.1016/j.chb.2020.106273

Callister, R. R., \& Wall, J. A. (2001). Conflict across organisational boundaries: Managed care organisations versus health care providers. Journal of Applied Psychology, 86, 754-763.

Carlton-Ford, S. L. (1992). Charisma, ritual, collective effervescence, and self-esteem. Sociology Quarterly, 33, 365-387.

Chadha, T. (2020). COVID-19: Impact on organisational culture. $B W$ People.http://wwwbwpeople.businessworld.in/article/COVID19-Impact-On-Organisational -Culture/15-04-2020-189253/.

Chin, W. W. (1998b). The partial least squares approach for structural equation modeling. In G. A. Marcoulides (Ed.), Modern Methods for business research (pp. 295-336). Mahwah, NJ: Lawrence Erlbaum Associates.

Charbonnier-Voirin, A., \& Roussel, P. (2012). Adaptive performance: Anew scale to measure individual performance in organisations. Canadian Journal of Administrative Sciences, 29(3), 280-293. 
Coffman, T., \& Harris, M. C. (1984). The U-curve of adjustment to adult life transitions. Paper presented at the meeting of the American Psychological Association, Toronto, Ontoria.

Conger, J. A., Kanungo, R. N., \& Menon, S. T. (2000). Charismatic leadership and follower effects. Journal of Organisational Behaviour, 21, 747-767.

Crant, J. M., \& Bateman, T. S. (2000). Charismatic leadership viewed from above: The impact of proactive personality. Journal of Organisational Behaviour, 21, 63-75.

Darwin, C. (2007). The expression of the emotions in man and animals (2nd ed.). NY: Dover Publications. (Original work published 1890).

Dean, R. A. \& Ferris, K. R., \& Konstans, C. (1985) Reality shock: Reducing the organizational commitment of professionals. Personnel Administrator, June, 139-148. Addison Wesley.

Deutsch, M., \& Gerard, H. B. (1955). A study of normative and informational social influences upon individual judgement. Journal of Abnormal and Social Psychology, 51, 629-636.

Dijkstra, T. K., \& Henseler, J. (2015). Consistent partial least squares path modeling. MIS Quarterly, 39(2) 297-316.

English, A. (2020). The office will remain vital for employee collaboration. Property Week. https://www.propertyweek. $\mathrm{com} /$ legal-and-professional/the-office-will-remain-vital-foremployee-collaboration/5109406.article

Feldman, D. C. (1976). A contingency theory of socialisation. Administrative Science Quarterly, 21, 433-454.

Ferlie, E., Fitzgerald, L., Wood, M., \& Hawkins, C. (2005). The nonspread of innovations: The mediating role of professionals. Academy of Management Journal, 48, 117-134.

Fisher, C. D. (1986). Organisational socialisation: An integrative review. Research, Personnel and Human Resources Management, 4, 101-145.

Fogarthy, T. J., \& Dirsmith, M. W. (2001). Organisational socialisation as instrument and symbol: An extended institutional theory perspective. Human Resource Development Quarterly, 12(3), 247-266.

Fornell, C., \& Larcker, D. F. (1981). Evaluating structural equation models with unobservable variables and measurement error. Journal of Marketing Research, 18(1), 39-50.

Frese, M. (1982). Occupational socialisation and psychological development: An underemphasized research perspective in industrial psychology. Journal of Occupational Psychology, $55,209-224$.

Gefen, D., Straub, D., \& Boudreau, M. (2000). Structural equation modeling and regression: Guidelines for research practice. Communications of the Association for Information Systems. https://doi.org/10.17705/1CAIS.00407 
Gotz, O., \& Liehr-Gobbers, K., \& Krafft, M. (2010). Evaluation of structural equation models using the partial least squares (PLS) approach. In V. E. Vinzi, W. W. Chin, J. Henseler, \& H. Wang (Eds.), Handbook of partial least squares (pp. 47-82). Springer Handbooks of Computational Statistics.

Grant-Vallone, E. J., \& Ensher, E. A. (2001). An examination of work and personal life conflict, organisational support, and employee health among international expatriates. International Journal of Intercultural Relations, 25(3), 261-278.

Griffeth, R. W., Hom, P. W., \& Gaertner, S. A. (2000). A metaanalysis of antecedents and correlates of employee turnover: Update, moderator tests, and research implications for the next millennium. Journal of Management, 26, 463-488.

Gross, M.A., \& Guerrero, L. K. (2000) Managing conflict appropriately and effectively: An application of the competence model to Rahim's organisational conflict styles. International Journal of Conflict Management, 11(3), 200-226.

Haidt, J. (2003). Elevation and the positive psychology of morality. In C. L. M. Keyes \& J. Haidt (Eds.), Flourishing: Positive psychology and the life well-lived (pp. 275-289). Washington, DC: American Psychological Association.

Hair Jr, J. F., Hult, G. T. M., Ringle, C., \& Sarstedt, M. (2016). A primer on partial least squares structural equation modeling (PLS-SEM). Sage Publications: Los Angeles.

Hair J. F., Ringle, C. M., \& Marko, S. (2011). PLS-SEM: Indeed a silver bullet. J Mark. Theory Pract. 19(2), 139-152.

Harris, D. (2017). The tenure curve: How tenure impacts employee engagement. Quantum workplace. https://www. quantumworkplace.com/future-of-work/the-tenure-curvehow-tenure-impacts-employeeengagement

Harrison, J. R., \& Carrol, G. R. (1991). Keeping the faith: A model of cultural transmission in formal organisations. Administrative Science Quarterly, 36, 552-582.

Hartig, T., Korpela, K., Evans, G. W., \& Gärling, T. (1996). Validation of a measure of perceived environmental restorativeness. Göteborg Psychological Reports, 26(7), 1-64.

Haueter, J. A., Macan, T. H., \& Winter, J. (2003). Measurement of newcomer socialisation: Construct validation of a multidimensional scale. Journal of Vocational Behaviour, 63, 20-39.

He, B., \& An, R., \& Berry, J. (2019). Psychological adjustment and social capital: A qualitative investigation of Chinese expatriates. Cross Cultural \& Strategic Management, 26(1), 67-92. https:// doi.org/10.1108/CCSM-04-2018-0054

Henseler, J., Ringle, C. M., \& Sinkovics, R. R. (2009). The use of partial least squares path modeling in international marketing. Advances in International Marketing, 20, 277-319. 
Hesketh, B., \& Neal, A. (1999). Technology and performance. In D. R. Ilgen \& D. P. Pulakos (Eds.), The changing nature of performance: Implications for staffing, motivation and development (pp. 21-55). San Francisco: Jossey-Bass.

Hill. W. F., \& Grüner, L. (1973). A study of development in open and closed groups. Small Group Behaviour, 4, 355-381.

Hollenbeck, J. R., LePine, J. A., \& Ilgen, D. R. (1996). Adapting to roles in decision making teams. In K. R. Murphy (Ed.), Individual differences and behaviour in organisations (pp. 300-333). San Francisco, CA: Jossey-Bass.

Hulin, C. L. (1991). Adaptation, persistence, and commitment in organisations. In M. D. Dunnette, L. M. Hough (Eds.), Handbook of industrial and organisational psychology (pp. 445-505). Palo Alto, CA: Consulting Psychologists Press.

Hulland, J. (1999) Use of partial least squares (PLS) in strategic management research: A review of four recent studies. Strategy Management Journal, 20, 195-204.

Immordino-Yang, M. H., \& Sylvan, L. (2010). Admiration for virtue: Neuroscientific perspectives on a motivating emotion. Contemporary Educational Psychology, 35, 110-115.

Immordino-Yang, M. H., McColl, A., Damasio, H., \& Damasio, A. (2009). Neural correlates of admiration and compassion. Proceedings of the National Academy of Sciences of the United States of America, 106, 8021-8026.

Inzerille, G., \& Rosen, M. (1983). Culture and organisational control. Business Research, 17, 281-292.

Irwin, R. (2007). Culture shock: Negotiating feelings in the field. Anthropology Matters, 9(1). https://www.anthropologymatters. com/index.php/anth matters/article/view/64/123

Jackson, S. E., Turner, J. A., \& Brief, A. P. (1987). Correlates of burnout among public service lawyers. Journal of Occupational Behaviour, 8, 339-349.

James, W. (1892). Psychology: The briefer course. New York: Holt.

Kammeyer-Mueller, J. D., Simon, L. S., \& Rich, B. L. (2012). The psychic cost of doing wrong: Ethical conflict, divestiture socialisation, and emotional exhaustion. Journal of Management, 38, 784-808.

Kaplan, R., \& Kaplan, S. (1989). The experience of nature: A psychological perspective. New York: Cambridge University Press. Republished by Ann Arbor, MI: Ulrich's 1995.

Kaplan, S. (1995). The restorative benefits of nature: Toward an integrative framework. Journal of Environmental Psychology, 15, 169-182. https://doi.org/10.1016/0272-4944(95)90001-2. 
Kaplan, S., \& Berman, M. G. (2010). Directed attention as a common resource for executive functioning and self-regulation. Perspectives on Psychological Science, 5(1), 43-57.

Katz, R. (1978). Job longetivity as a situational factor in job satisfaction. Administrative Science Quarterly, 23, 204-223.

Kennedy, D. J., \& Berger, F. (1994). Newcomer socialisation: Oriented to facts or feelings? Cornell Hotel and Restaurant Administration Quarterly, 35(6), 58-71. https://doi.org/ $10.1177 / 001088049403500613$

Khalil K. et al. (2021). An empirical study on organisational socialisation and its relationship with employees' age and the knowledge management. In: Ayaz H., Asgher U. (Eds.), Advances in neuro ergonomics and cognitive engineering. AHFE 2020. Advances in Intelligent Systems and Computing, vol 1201. Springer, Cham. https://doi.org/10.1007/978-3-030-51041-1_47

Kim, T. Y., Cable, D. M., \& Kim, S.P. (2005). Socialisation tactics, employee proactivity, and person-organisation-fit. Journal of Applied Psychology, 90(2), 232-241.

Kinder, D. R., \& Sears, D. O. (1985). Public opinion and political action. In G. Lindzey \& E. Aronson (Eds.), The handbook of social psychology (pp. 659-742) (3rd edn.). New York: Random House.

Klineberg, O. W., \& Frank, H. (1979). At a foreign university: An international study of adaptation and coping. New York: Praeger.

Koestenbaum, P. (2002). Leadership: The inner side of greatness, a philosophy for leaders, new and revised. Jossey-Bass: San Francisco.

Kristof-Brown, A. L., Zimmerman, R. D., \& Johnson, E.C. (2005). Consequences of individuals' fit at work: A meta-analysis of person-job, person-organisation, person-group, and personsupervisor fit. Personnel Psychology, 58(2), 281-342.

Krosnick, J. A., \& Alwin, D. F. (1989). Aging and susceptibility to attitude change. Journal of Personality and Social Psychology, $57,416-425$.

Kumar, N., Scheer, L., \& Steenkamp, J. (1995). The effects of perceived interdependence on dealer attitudes. Journal of Marketing Research, 32(3), 348-356.

Lahana, E., Tsaras, K., Kalaitzidou, A., Galanis, P., Kaitelidou, D., \& Sarafis, P. (2017). Conflicts management in public sector nursing. International Journal of Healthcare Management. http://dx.doi.org/10.1080/20479700.2017.1353787

Latan, H., \& Ghozali, I. (2012a) Partial least squares: Concept, technique and application SmartPLS 2.0 M3. Badan Penerbit Universitas Diponegoro: Semarang. 
Laumann, K., Gärling, T., \& Stormark, K. M. (2001). Rating scale measures of restorative components of environments. Journal of Environmental Psychology, 21(1), 31-44. https://doi. org/10.1006/je.2000.0179

Lee, T. W., \& Mitchell, T. R. (1994). An alternative approach: The unfolding model of voluntary employee turnover. Academy of Management Review, 19, 51-89.

Lesser, S. O., \& Peter, H. W. S. (1957). Training foreign nationals in the United States. In R. Likert \& S. P. Hayes (Eds.), Some applications of behavioural research. Paris: UNESCO.

Levinthal, D. A., \& Fichman, M. (1988). Dynamics of interorganisational attachments: Auditor-client relationships. Administrative Science Quarterly, 33(3), 345-369.

Li, J., \& Fischer, K. W. (2007). Respect as a positive self-conscious emotion in European Americans and Chinese. In J. L. Tracy, R. W. Robins, \& J. P. Tangney (Eds.), The self-conscious emotions: Theory and research (pp. 224-242). New York, NY: Guilford Press.

London, M., \& Mone, E. M. (1999). Continuous Learning. In D. R. Ilgen \& D. P. Pulakos (Eds.), The changing nature of performance: Implications for staffing, motivation and development (pp. 119-153). San Francisco: Jossey-Bass.

Louis, M. (1980). Surprise and sense making: What newcomers experience in entering unfamiliar organisational settings. Administrative Science Quarterly, 25, 226-251.

Lysgaard, S. (1955). Adjustment in a foreign society: Norwegian fulbright grantees visiting the United States. International Social Science Bulletin, 7, 45-51.

March, J. G., \& Simon, H. A. (1958). Organisations. New York: Wiley. McDonough, G., \& Fallon, C., \& Keane, D. (2020). COVID-19: Protecting and nurturing organisational culture among your workforce.https://www.pwc.ie/issues/covid-19/protectingnurturing-organisational-culture-workforce.html

Meek, V. L. (1988). Organisational culture: Origins and weaknesses. Organisational Studies, 9(4), 453-473.

Modlin, H., \& Faris, M. (1956). Group adaptation and interaction in psychiatric team practice. Psychiatry, 19, 97-103.

Moreland, R. L., \& Levine, J. M. (2001). Socialisation in organisations and work groups. In M. E. Turner (Ed.), Groups at work: Theory and research (pp. 69-112). Mahwah, NJ: Erlbaum.

Nelson, D. L. (1987). Organisational socialisation: A stress perspective. Journal of Occupational Behaviour, 8(4), 311324. http://dx.doi.org/10.1002/job.4030080404 
Nifadkar, S. S., \& Bauer, T. N. (2016). Breach of belongingness during socialisation: Newcomer relationship conflict, information, and task-related outcomes. Journal of Applied Psychology, 101, 1-13. https://doi.org/10.1037/apl0000035

Oberg, K. (1955). Types of social structure among the lowland tribes of south and central America. American Anthropology, 57, 472- 487.

Oberg, K. (1960). Cultural shock: Adjustment to new cultural environments. Practical Anthropology, 7, 177-182.

Ortony, A., Clore, G. L., \& Collins, A. (1988). The cognitive structure of emotions. New York, NY: Cambridge University Press.

Othman, Siti Zubaidah \& Shkuri, Nur Syafiqah Mohd. (2015). Predicting turnover intention through organisational support and organisational commitment: The case of a manufacturing company. International Journal of Management Studies, 22(1), 33-45.

Oxenfeldt, M. R., \& Anthony, O. K. (1968). Will successful franchise systems ultimately become wholly-owned chains. Journal of Retailing, 44(4), 69-83.

Parsons, C. S. (2018). Learning the ropes: The influence of the roundtable classroom design on socialisation. Journal of Learning Spaces, 7(2). https://files.eic.ed.gov/fulltext/ EJ1200612.pdf

Pedersen, P. (1995). The five stages of culture shock: Critical incidents around the world. London: Greenwood Press.

Peterson, C., \& Seligman, M. E. P. (2004). Character strengths and virtues: A handbook and classification. New York: Oxford University Press.

Peterson, R. S., \& Behfar, K. J. (2003). The dynamic relationship between performance feedback, trust, and conflict in groups: A longitudinal study. Organisational Behaviour and Human Decision Processes, 92, 102-112.

Pondy, L. R. (1969), Varieties of organisational conflict. Administrative Science Quarterly, 14, 499-505.

Pondy, L. R. (1992). Reflections on organisational conflict. Journal of Organisational Behaviour, 13, 257-261.

Porter, L. W., Lawler. E. E., \& Hackman, J. R. (1975). Behaviour in organisations. New York: McGraw-Hill.

Pulakos, E. D., Arad, S., Donovan, M. A., \& Plamondon, K. E. (2000). Adaptability in the work place: Development of taxonomy of adaptive performance. Journal of Applied Psychology, 85(4), 612-624.

Quick, J. C., \& Quick, J. D. (1984). Organisational stress and preventive management. New York: McGraw-Hill. 
Rahim, A. (1977). The management of organisational intergroup conflict: A contingency model. 8th Annual Meeting of the Midwest American Institute for Decision Sciences (pp. 247249). Cleveland, Ohio.

Rattner, J., \& Danzer, G. (2006). Selbstverwirklichung: Seelische hygiene und sinnsuche im dasein [Selfactualization: Psychic hygiene and the search for meaning in being]. Würzburg, Germany: Ko"nigshausen \& Neumann. In Ines Schindler, Veronika Zink, Johannes Windrich \& Winfried Menninghaus (2013) Admiration and adoration: Their different ways of showing and shaping who we are. Cognition and Emotion, 27(1), 85-118. https://doi.org/10.1080/02699931.2012.698253

Rojas, F. (2017). Theory for the working sociologist. New York: Columbia University Press.

Ross, R., \& Ross, J. (1989). Small groups in organisational settings (pp. 139-178). Englewood Cliffs, NJ: Prentice-Hall.

Saks, A. M., \& Ashforth, B. E. (1997). Organisational socialisation: Making sense of the past and present as a prologue for the future. Journal of Vocational Behaviour, 51, 234-279.

Saks, A. M., Krista, L. U., \& Neil, E. F. (2007). Socialisation tactics and newcomer adjustment: A meta-analytic review and test of a model. Journal of Vocational Behaviour, 70, 413-446.

Schein, E. H. (1968). Organisational socialisation and the profession of management. Industrial Management Review (MIT), 9, 1-15.

Schein, E. H. (1971). The individual, the organisation, and the career: A conceptual scheme. Journal of Applied Behavioural Science, 7, 401-426.

Schein, E. H. (1990). Organisational culture. American Psychologist, 45(2), 109-119. https://doi.org/10.1037/0003-066X.45.2.109

Schein, E. H. (1978). Career dynamics: Matching individual and organisational needs. Boston: Addison-Wesley Publishing.

Schindler, I., Zink, V., Windrich, J., \& Menninghaus, W. (2013). Admiration and adoration: Their different ways of showing and shaping who we are. Cognition and Emotion, 27(1), 85-118. https://doi.org/10.1080/02699931.2012.698253

Sigelman, C. K., \& Shaffer, D. R. (1991). Life-span human development. Pacific Grove, CA: Brook Cole.

Smith, R. H. (2000). Assimilative and contrastive emotional reactions to upward and downward social comparisons. In J. Suls \& L. Wheeler (Eds.), Handbook of social comparison: Theory and research (pp. 173-200). New York, NY: Kluwer Academic.

Solomon, R. C. (1993). The passions: Emotions and the meaning of life. Indianapolis. Hackett Publishing. 
Steel, R. P. (2002). Turnover theory at the empirical interface: Problems of fit and function. Academy of Management Review, 27, 346-360.

Steers, R. M., \& Mowday, R. T. (1981). Employee turnover and postdecision accommodation processes. In L. Cummings \& B. Staw (Eds.), Research in organisational behaviour (pp. 255281). Greenwich, CT: JAI Press.

Tasselli, S. (2018). Love and organisation studies: Moving beyond the perspective of avoidance. Organisation Studies. https://doi. org/10.1177/0170840617747924

Thomas, K. W. (1992). Conflict and negotiation processes in organisations. In M. Dunnette and L. Hough (Eds.), Handbook of industrial and organisational psychology (pp. 651-718). Palo Alto, CA: Consulting Psychologists Press.

Thrash, T. M., \& Elliot, A. J. (2004). Inspiration: Core characteristics, component processes, antecedents, and function. Journal of Personality and Social Psychology, 87, 957-973.

Tuckman, B. (1965). Developmental sequence in small groups. Psychological Bulletin, 63(6), 384-399.

Van Maanen J., \& Schein, E. (1979). Toward a theory of organisational socialisation. In Staw B (Ed.), Research in organisational behavior (pp. 209-264). Greenwich: JAI Press.

Walker, H. J., Bauer, T. N., Cole, M. S., Bernerth, J. B., Feild, H. S., \& Short, J. C. (2013). Is this how I will be treated? Reducing uncertainty through recruitment interactions. Academy of Management Journal, 56(5), 1325-1347.

Wanous, J. P. (1980). Organisational entry. Reading, MA: AddisonWesley.

Ward, C., Okura, Y., \& Kennedy, A., \& Kojima, T. (1998). The U-curve on trial: A longitudinal study of psychological and sociocultural adjustment during cross-cultural transition. International Journal of Intercultural Relations, 22, 277-291.

Yang, Jen-Te. (2008). Effect of Newcomer socialisation on organisational commitment, job satisfaction, and turnover intention in the hotel industry. The Service Industries Journal, 28(4),429-443.http://dx.doi.org/10.1080/02642060801917430

Zabusky, S. E., \& Barley, S. R. (1997). You can't be a stone if you're cement: Reevaluating the emic identities of scientists in organisations. In B. M. Shaw (Ed.), Research in organisational behaviour (pp. 19, 404). Greenwich, CT: JAI Press. 